\title{
PACKAGING THROUGH TIME
}

\author{
Stanislav Bolanča, Nikola Mrvac, Martina Hajdek \\ University of Zagreb, Faculty of Graphic Arts
}

\section{The task of packaging}

Packaging can be briefly defined as a science, method and technology for product preservation. The function of packaging is to protect the product that is packed in it and to protect the environment from the content inside the packaging. As a result, the products can be gaseous, liquid or solid.[1-3] The packaging must be suitable for use, i.e. handling, transport and distribution. It should inform the potential and the actual buyer and it should "sell the product". [4,5]

An important part of the packaging design is the material from which it will be made. The basic conditions that packaging must meet are the following: strength on material pressure, elasticity, plasticity, stiffness and resistance to strain, toughness, mechanical endurance and printing.[4]

Packaging must protect the content and be protected itself from oxidation, moisture, odor, chemical agents and microbes. To meet these requirements, polymer materials and nanotechnology are now being used. $[5,6]$

Packaging can also be made according to the materials, purpose in traffic, durability and function. [6-8]

Classification according to materials: wood, paper, cardboard, fabric, clay, glass, metal, polymers, multilayer materials.

Classification according to the traffic purpose: sales or primary, group or secondary, transport or tertiary.

Classification according to durability: return, non-refundable (onetime).

Classification according to function: warehouse transport, sales, use. $[9,10]$

\section{Materials and packaging in the past}

Packaging is a formed material that goods are wrapped in or placed within.[1] Packaging was in every historical period adapted to the civilizational and technological level of the society.[11] There is information on packaging from 12000 years ago. It was used by people who lived as nomads, hunters, and gatherers of fruits.[4] At that time, hollow trees, tickles, animal bladders and skin were used as packaging materials. Flexible leaves were joined with flexible grass. Later, leather reusable bags and wicker bags were made. [1] Today, people who are at a low level of development use leaves, leather and wicker products as packaging.

After the mentioned materials, materials with new and better properties were found. The first great progress of civilization was reflected in the production and use of pottery vessels. Some of those items were beautifully painted. The earthen colors were the most commonly used, and the durability of their lightness is appreciated because the drawings are hence well preserved.[12]

Glass appeared around 7000 BC. Around the year $6000 \mathrm{BC}$ is when serial production of glass and wood for packaging began.

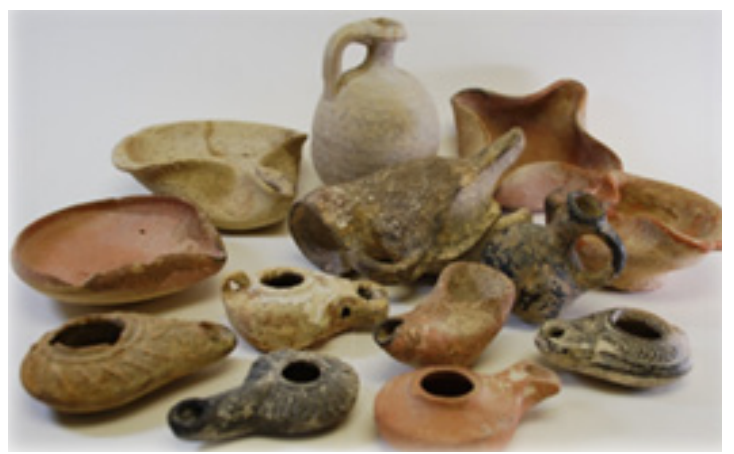




\section{Figure 1. Ceramic and glass from 5000 BC[13]}

In our region, the most famous finding site of ceramic vessels is Vučedol. The vessels date from the period between 2800 and 2400 BC. The most famous vessel is a thurible in the shape of a partridge or dove. The vessel is known as "The Vučedol Dove (Vučedolska golubica)." [14,15]

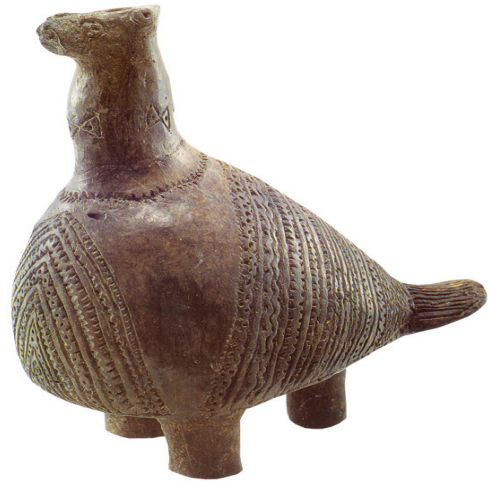

Figure 2. The Vučedol Dove[14,16]

The glass industry started in Egypt around 1500 BC. Around 1200 years BC cups and

Figure 3. Bottles from Egypt made around the year $1200 \mathrm{BC}$ and jars of semi-transparent and transparent glass made some time later.[13,17]

Today, the most widespread material for packaging production is paper, i.e. cardboard. [18] The development of fiber-based substrates for writing begins with papyrus in Egypt and paper in China. Approximately from the year 200 to $220 \mathrm{BC}$, paper in China appeared as a wrapping material, i.e. as packaging. It was then that the idea that paper can be used in the transport of certain goods appeared. Thus, in the 6th century, China started producing paper bags. [4] Similarly, the use of paper began in Europe around the year 1000. It was recorded in England in 1310, in Germany in 1390 and in America in 1609.[13,17,19]

Naturally, other materials were developed simultaneously. Thus, in the 13th century, in Bohemia, metal-coated packaging appeared. In Germany, iron cans coated with tin were made in the 14th century.[20] Such cans met the required conditions, thus food was placed in them. In the 16th century, that process was also used in America.[13]

\section{The appearance of printed packaging}

The first reproductions of the original date back to the year 3000 BC in Mesopotamia. What was copied were texts that were imprinted in clay tiles.[21] At that time, China and India used the stamping technique for printing.[1-3] In the late prehistoric times, the technique of silk screening was used in Asia and Europe. Stone blocks and bronze were used as a print form in Asia from the 4th to the 6th centuries. Later, in the 9th century, wood clutches were made in China, and from the 11 th to the 13th century there were movable signs set into print forms.

In parallel with the development of the copywriting technology, the development of packaging was being developed. In the 9th century, there was already a very high quality of bronze packaging. In Europe, packaging of
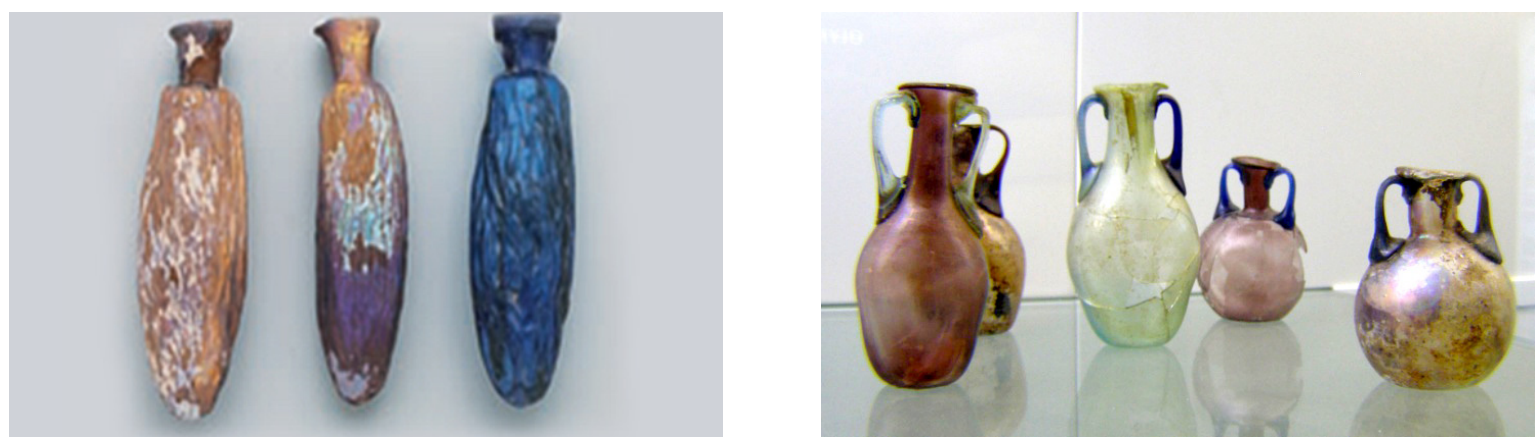

bowls were pressed in molds. Around 300 years BC the Phoenicians were producing transparent glass.[17] 
animal origin was being produced (in 1284, the Horners Company, London). The horns and shields of animals were processed with the packaging. Wool and fabric of plant origin were also used for making sacks.

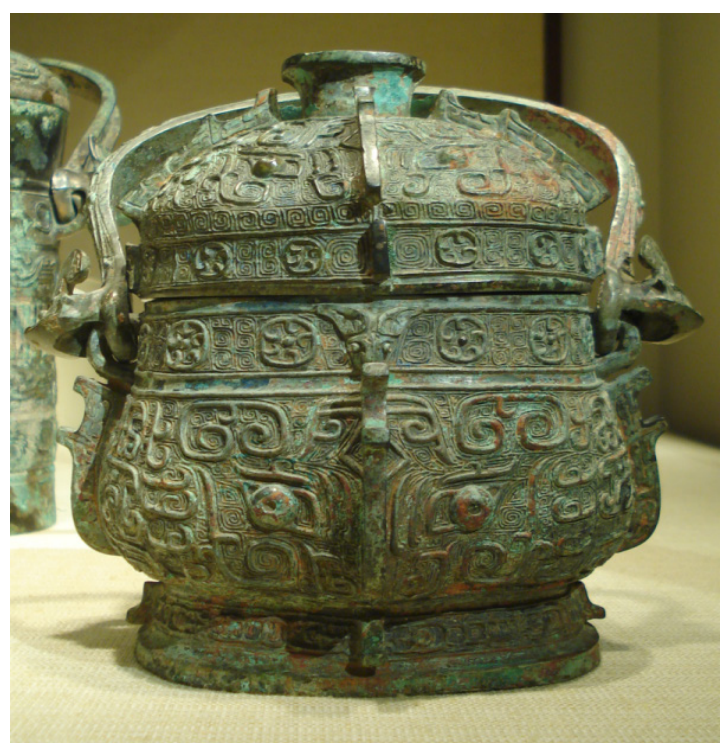

Figure 4. Bronze box from the 9th century[22]

In the 14th century, movable bronze signs were used in Korea.[4,23,24] At that time, gravure printing and screen printing were used. Johann Gutenberg's innovation from 1440 enabled industrial printing, lower prices and larger prints.[25-27] That gave an additional boost to the production of packaging that is increasingly being printed, and it thus took on a role it still has today.

At the end of the 14th century, paper mills appeared in Europe, i.e. the production of paper and cardboard production improved. In the 16th century, hundreds of book binderies opened. A century later, the production of padded carton boxes for doses, scents, jewelry, watches, cutlery, and similar goods that needed protection began.[17] Those boxes often had prints, which marked the beginning of informing the user and of product advertising. In 1764 , tin boxes for tobacco were produced in London.

With the emergence of new materials and machinery in the 19th century, a rapid industrial development of packaging production began, which was in line with the degree of civilization and standards, and in accordance with the demands of the society.
Development was mostly concentrated in Europe and America. Thus, in the 1800s, fiberbased paper-making machines were used, and that same year monochrome printed labels appeared in the USA. ${ }^{1}$ Moreover, that same year, the permanent storage of food in glassware was solved. Food was heated up to $100^{\circ} \mathrm{C}$, and closed into jars with an airtight system. In 1804, metal tins for food preservation appeared. Their mass production was recorded in the days of the Napoleonic wars.[20] In 1823, the Englishman Peter Dured patented the production of canned food. The industrial production of cans in the United States started in 1866.[13]

Paper packaging also expanded. In 1817, the English began producing paper bags. That production was transformed into commercial industry in 1844. In 1850, the commercial production of cardboard boxes and corrugated cardboard boxes began. In the United States, the sack machine was launched in 1852.[28] In the meantime, in 1831 , styrene was discovered, and in 1835 , vinyl chloride was discovered, a raw material used in later times.[29] In 1977, polyethylene terephthalate came into use.[20]

New technologies were found in order to satisfy the hectic production of printed books and packaging. In 1867, the production of cellulose and paper from tree pulp began, which was a big step forward.[28] In 1870, Margaret Knight patented a new machine for making paper bags.[3] A major step in the packaging industry was also the introduction of a steam generating plant for the production of wooden packaging boxes. $[9,30,31]$ In 1889 , machines for the production of glass bottles were also introduced.[10,28]

\section{New age (twentieth century)}

Until the nineteenth, and especially in the twentieth century, packaging increasingly coincided with printing. What was mostly used were the gravure printing, letterpress printing, screen printing for smaller prints, and their place was increasingly occupied by the lithographic printing process. The lithography was initially a direct printing process with a stone printing form and then a metal printing form, and later it became an offset technology.[32] 
In 1818, Alois Senefelder secured patent rights for his invention of lithography. In 1820 , the color printing by a lithographic process with the use of several printing forms was introduced.[29,32] By putting an offset cylinder into a lithographic machine in 1904, Ira Washington Rubel constructed the first lithographic offset. That is how a high quality printing technique was born.[33] Almost simultaneously, in 1905, in Petersburg, the inventor Orlov constructed an offset machine with a high printing form, a dry offset. This technique initially printed money and was later mostly used to print packaging.[34] Already in 1907, Carl Holweg patented aniline printing. That technique of high printing is called flexography due to its elastic high form. Today, that printing technology is often referred to as packaging printing, as that is its main activity.[35,36]

As other branches of technology advance, graphic technology advances as well, finding new ways to duplicate the original. With the emergence of computers, digital printing is developed, and it enables a more profitable printing of a smaller number of editions and product personalization. That is the technique of the present and future of smaller editions. Following the global advancement for duplicating the original, 3D technology and some other, still small technologies are being used.

The technological progress resulted in a rise in living standards, which also brought changes in packaging requirements. The packaging,

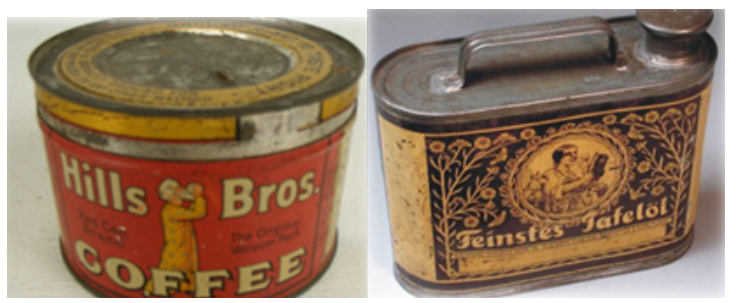

Figure 5. Printed cans from the 19th century[13] besides the fact that it enveloped goods, had to also highlight the content and amount, i.e. the amount of the product in the packaging, in order to inform the buyer. Packaging needed to facilitate the transportation and sale of the product. It had to protect the product from pollution, damage and theft. It needed to emphasize the necessary information and the color and design needed to make it look attractive. To meet these requirements, new packaging was created.

New materials were developed and used. After printing on fiber-printed substrates, in 1866, printed cans appeared in stores.[13]

Naturally, new materials are also desirable for a complete development of packaging. Therefore, in 1870, John Wesley Hyatt found the plastic material he called celluloid.[13] The basis for obtaining plastics was sought in natural polymers: keratin from the horns of animals, animal shields, skin, fur, nails and rubber. When looking for new solutions, in 1907, Leo Hendrik Baekeland produced and was the first to use the polymer material of bakelite material for commercial purposes. $[3,13]$

Parallel advances were being made to the already well-known production. Machines for sewing paper bags were used since 1905 . Later, in 1925, printing on the bags became multicolor.[2] The packaging that now covers the majority of the market is also of fibrous origin. It is the packaging made of corrugated cardboard, which came into play in 1910 .

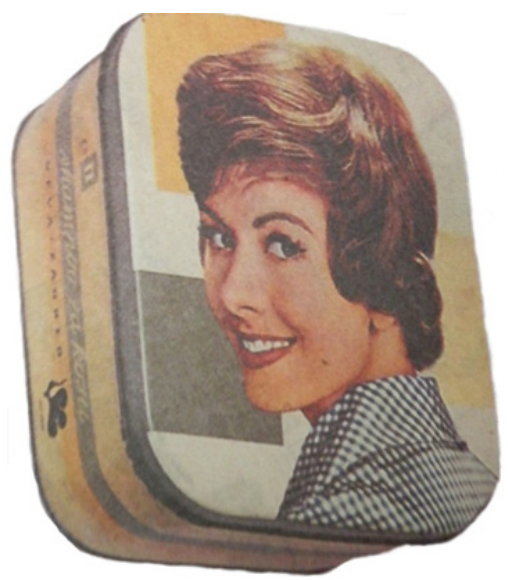

Figure 6. Aluminum packaging for a shampoo from 1950[37] 
It was first used as packaging in maritime transport. [28]

That same year, in 1910, the production of aluminum foil for product wrapping began. The commercial use of aluminum cans as trade packaging appeared in the year 1950 . Nine years later, the trend of packing food in aluminum cans began.[13] When it comes to polymers, it should be mentioned that styrene entered into wide use in 1950.

Between 1900 and 1960, glass was the dominant material for the production of packaging for liquids. At that time, automatic machines which produced 20000 bottles per day were used. [28] Glass is inert to climate change, resistant to almost any chemical, can be transparent or colored. However, glass also has its shortcomings. It is heavy, hard, relatively expensive, and only a very limited number of printing techniques can be used on it.

During the time in which glass was the dominant material, what also began to develop was the packaging of polymeric materials. It reached its full development around 1950. Plastic packaging is suitable for packing liquids, but also for most other substances. Different boxes, bottles, bags and foils are formed from it. It is not hard; it is light and resistant to most chemicals. The majority of polymer packaging can be recycled. Plastic packaging is easy to transport. Different designs can be applied to it. It prints well, which is why instructions and warnings can also be printed on it, together with the advertisement. Its negative property is that it is not resistant to elevated temperature - it softens at around $80^{\circ} \mathrm{C}$.[38-40] Today, about 80000000 tons of plastic packaging is produced annually, with a tendency for a steady growth. It must not be disposed of on landfills because it has an extremely long time of dissolution. New plastic materials are trying to avoid this shortcoming. When looking for better solutions, plastics embedded with plant fibers is also taken into consideration.

Around 1970, with the fibrous materials such as glass and plastics, a very important place, with a tendency for growth, was taken by metal packaging, especially aluminum. It is light, inert on food and many chemicals and weathering. It is easy to recycle and is suitable for many printing techniques.[41]

Packaging made of polyethylene terephthalate emerged in 1977.[42] This polymeric material quickly conquered the market, becoming one of the most important resources for packaging by 1980 .

To produce even better materials, one direction of the research was to combine different materials into a unified whole. Different materials were brought together in different combinations, so that each of them would give its best for the final "sandwich" material. New materials that were tailored to specific product specifications were created. Paper, cardboard, aluminum and polymeric plastic materials were used as the basis for making sandwich materials. [43,44]

As an example, the composition of two sandwich materials is listed:

$\begin{array}{ll}\text { lacquer } & \text { polyester } \\ \text { graphic imprint } & \text { graphic imprint } \\ \text { cardboard } & \text { glue } \\ \text { glue } & \text { paper } \\ \text { aluminum } & \text { glue } \\ & \text { aluminum } \\ & \text { glue } \\ & \text { polyethylene }\end{array}$

Examples of multi-layered sandwich materials for the production of packaging

These new materials give excellent results while taking into account the possibilities of their disposal, since packaging is most often a one-time disposable product. [11]

\section{Summary}

The development of packaging was gradual. Initially, the changes took place slowly, but with the faster development of the society, the subsequent changes also accelerated. The development of technology was slow and largely conditioned by the development of new materials.[28,43] In accordance with those processes, packaging was developed, as it can be seen from Table 1 . 
Table 1. A comparison of the development of the materials and packaging

\begin{tabular}{|c|c|}
\hline Materials & Packaging \\
\hline $120^{\text {th }}$ century $\mathrm{BC}-$ materials directly from the nature & objects found directly in the nature \\
\hline ceramic & ceramic pots for liquids and solids \\
\hline $70^{\text {th }}$ century BC - glass & glasses, bowls \\
\hline $60^{\text {th }}$ century BC - glass and wood & bottles, chests \\
\hline $50^{\text {th }}$ century BC & various bowls \\
\hline $30^{\text {th }}$ century BC - clay tiles & writing text \\
\hline $30^{\text {th }}$ century BC - silk & wrapping \\
\hline $3^{\text {rd }}$ century BC - transparent glass & transparent and colored bottles \\
\hline $2^{\text {nd }}$ century & wrapping paper \\
\hline $4^{\text {th }}-6^{\text {th }}$ century & stone and bronze as printing forms \\
\hline $6^{\text {th }}$ century - paper & paper bags \\
\hline $9^{\text {th }}$ century - wool, linen, hemp & bags \\
\hline $9^{\text {th }}$ century - bronze & bronze packaging \\
\hline $13^{\text {th }}$ century - metals & metal-coated packaging \\
\hline $14^{\text {th }}$ century - iron, tin, cellulose & iron- and tin-coated cans, metal signs \\
\hline $15^{\text {th }}$ century - silk printing & ductile packaging \\
\hline $16^{\text {th }}$ century - cardboard & binderies, food is placed into cans \\
\hline $18^{\text {th }}$ century - paper machine & label printing \\
\hline $19^{\text {th }}$ century - protected metal & containers \\
\hline $19^{\text {th }}$ century - vinyl chloride & machines for making bags, glass bottles; litography \\
\hline $20^{\text {th }}$ century - bakelite, corrugated cardboard & offset, transport packaging, plastic packaging \\
\hline $20^{\text {th }}$ century - polymeric materials & plastic packaging boom \\
\hline $20^{\text {th }}$ century - sandwich materials & diverse packaging \\
\hline
\end{tabular}

Packaging and the materials for packaging production are still in line with the civilizational and technological development

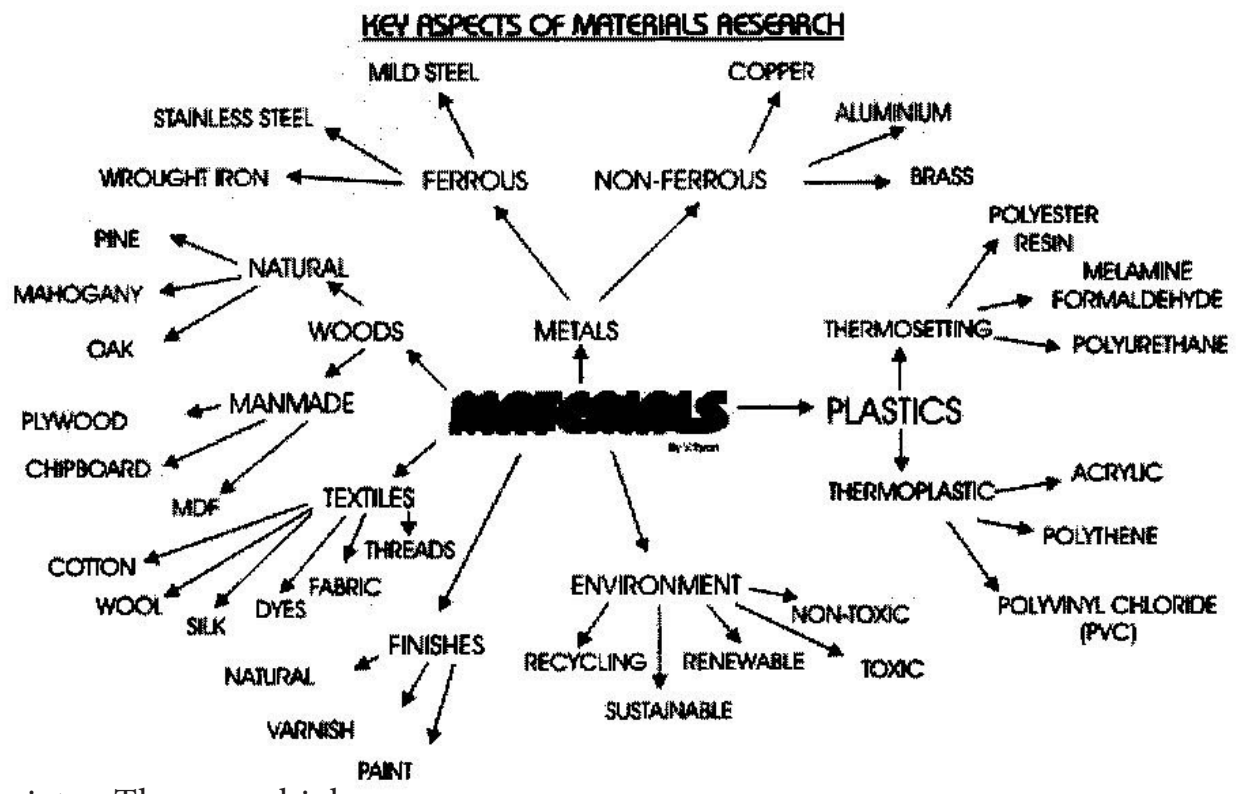

of the society. The ever-higher consumer 
standard and the ever-increasing competition of vendors causes the designer's demand for new and different materials.[45] However, some materials remain unavoidable on the market.[46,47] The following picture shows some important aspects of the study of materials.

\section{Figure 7. Materials for packaging production[48]}

Packaging was initially located at the manufacturer of goods that were to be packaged. By the end of the nineteenth century, there was an emergence of an industry that produced packaging for external users. It is there that, according to the needs, printed packaging became increasingly used, which is how packaging obtained the tasks it has today.

The life cycle of packaging is complex. It consists of commerce, design, technical production of packaging, packaging, transport and storage, purchasing, product consumption and waste disposal.

Once we choose the material and produce the packaging, it goes to use. Unfortunately, most packaging is intended to be used only once. After that, it becomes waste that is scattered around the globe.

The waste $\mathrm{kg}$ per person per day is around:

USA 2.04; Iceland 1.99; the Netherlands 1.67; the United Kingdom 1.58; France 1.45; Japan 1.13; Canada 0.95; Mexico 0.86. [49]

The discarded waste in the world can be listed as follows: paper and wood $27 \%$, plastics $8 \%$, glass $8 \%$, biological waste $40 \%$, other waste $11 \%$.

The discarded packaging in Croatia can be listed as follows: $3.8 \%$ wood, $34 \%$ paper and cardboard, 3\% metal packaging, $47 \%$ glass packaging, $12 \%$ plastic packaging.

Packaging waste can be divided into industrial waste, trade waste and household waste.

> Industrial waste:

transport and sales packaging

homogenous composition

no major problems in recycling or destruction $[8,43]$

> Waste in stores: non-returnable transport and bulk

packaging

mostly homogenous

no major problems in recycling or destruction $[8,43]$

> Home waste:

non-returnable and transport packaging

mixed with other different materials

very non-homogenous material

discarded packaging participates with $60 \%$

$[8,43]$

> Dispensing waste for recycling after

dispensing paper, cardboard and

paperboard:

magnetic dispensing or iron

aluminum dispensing (cans)

glass dispensing (by colors)

plastic dispensing

other waste

Through recycling or some other means of disposal, today's packaging ends its life span.

The future desires less and less unnecessary packaging, from materials that are easily recycled and that consume as little energy as possible throughout the process.

The trend in the world is that the amount of packaging is constantly increasing. This is a consequence of the constant increase in the number of inhabitants of the Earth. Also, by the disappearance of large, and growing numbers of small families or individuals, there is a growing need for more small packages. Likewise, the rise in the standard of living has the effect of increasing the number of packaging.

Further increase in demand for different small pack sizes is expected, and consequently increase the number of machines that are more profitable to print smaller prints and can personalize the products. Classical printing technologies will only be held for printing large prints, but often with a possibility of personalization in printing. 


\section{Refrences}

1. Verpackung. In: Wikipedia [Internet]. 2019 [cited 2019 Oct 9]. Available from: https://de.wikipedia.org/w/index. php?title=Verpackung\&oldid $=189700771$

2. Povijest ambalaže [Internet]. Coolinarika. [cited 2019 Oct 9]. Available from: https://www.coolinarika. com/clanak/povijest-ambalaze/

3. Hult M, Nilsson P.: Packaging in the New Product Development Process An International Perspective [Internet].2019 [cited 2019 Oct 9]. Available from: https://www.diva-portal.org/smash/get/diva2:3925/ FULLTEXT01.pdf

4. Griffey H, Thurow S.; Die Geschichte der Verpackung [Internet]. LUSH Deutschland. 2017 [cited 2019 Oct 9]. Available from: https://de.lush. com/artikel-die-geschichte-der-verpackung

5. Muhamedbegović B, Juul NV, Jašić M. Ambalaža i pakiranje hrane. Teh Fak Tuzla -Set Tuzla. 2015;

6. Packaging and labeling [Internet]. 2019 [cited 2019 Oct 9]. Available from: https:// https://en.wikipedia. org/wiki/Packaging_and_labeling

7. Geschichte der Verpackung [Internet]. [cited 2019 Oct 9]. Available from: https://www.schweizerverpackung.ch/html/geschichte_der_verpackung. html

8. Stipanelov Vrandečić N. Ambalaža [Internet]. [cited 2019 Oct 9]. Available from: http://www.sraspopovic. com/Baza\%20znanja\%20dokumenti/Polj.i\%20 prehr/I\%20razred/ambalaza\%201.pdf

9. Risch SJ. Food Packaging History and Innovations. J Agric Food Chem. 2009 Sep 23;57(18):8089-92. doi: 10.1021/jf900040r

10. Schueneman H, Tollete B.: A Critical Overview of the Package Development Process. In 2010. p. 18-21. TAPPI PLACE CONFERENCE, 2010

11. Bolanča S. Tisak ambalaže. Hrvatska Sveučilišna Naklada; 2013. ISBN 978-953-169-252-6

12. Verpackung: Interview Plastikhormone [Internet]. 2014 [cited 2019 Oct 9]. Available from:http://149.219.201.57/technik/werkstoffe/ verpackungen/index.html

13. Packaging Manufacturers Association [Internet]. [cited 2019 Oct 9]. Available from: http://ambalaj. org.tr/en/environment-history-of-packaging.html

14. Vučedolska golubica - Metapedia [Internet]. [cited 2019 Oct 9]. Available from: https://hr.metapedia. org/wiki/Vu\%C4\%8Dedolska_golubica

15. Administrator. Muzej vučedolske kulture [Internet]. Muzejska Udruga Istočne Hrvatske. [cited 2019 Oct 10]. Available from: https://www.muih.hr/muzejvucedolske-kulture

16. Vučedolska golubica. In: Wikipedija [Internet]. 2018 [cited 2019 Oct 9]. Available from: https://hr.wikipedia.org/w/ index.php?title =Vu \% C 4\%8 Dedolska_ golubica\&oldid $=5143301$

17. Keine Ruhe im Karton. Eine kleine Geschichte der Verpackung [Internet]. DGPT. [cited 2019
Oct 9]. Available from: https://dgpt.org/produkt/ keine-ruhe-im-karton-eine-kleine-geschichte-derverpackung/

18. Stričević N. Suvremena ambalaža. Školska knjiga; 1982.

19. Verpackung [Internet]. [cited 2019 Oct 11]. Available from: http://www.tis-gdv.de/tis/verpack/inhalt1.htm

20. History of Paper Packaging \& Paper Carrier Bags [Internet]. Keenpac. 2018 [cited 2019 Oct 10]. Available from: https://keenpac.com/paper-carrierbags

21. The Evolution of the book [Internet]. [cited 2019 Oct 10]. Available from: https://sfbook.com/theevolution-of-the-book.htm

22. Packaging and labeling. In: Wikipedia [Internet]. 2019 [cited 2019 Oct 10]. Available from: https:// en.wikipedia.org/w/index.php?title=Packaging_and_ labeling\&oldid=919539475

23. Barrett TH. The woman who discovered printing. Yale University Press; 2008. ISBN: 9780300127287

24. Chia L, De Weerdt H. Knowledge and text production in an age of print: China, 900-1400. Brill; 2011. ISBN: 978-90-04-19228-7

25. Kilgour FG. The evolution of the book. Oxford University Press, USA; 1998. ISBN: 9780195118599

26. Johannes Gutenberg. In: Wikipedia [Internet]. 2019 [cited 2019 Oct 10]. Available from: https:// en.wikipedia.org/w/index.php?title=Johannes_ Gutenberg\&oldid $=917426225$

27. Bolanča S, Majnarić I, Modrić D. Press-world milestone and Croatia. Acta Graph Znan Časopis Za Tisk Graf Komun. 2017;28(2):59-78. doi. org/10.25027/agj2017.28.v28i2.134

28. Berger KR. A brief history of packaging. University of Florida Cooperative Extension Service, Institute of Food and ...; 2002. [Internet]. 2019 [cited 2019 Oct 15] Available from https://ufdc.ufl.edu/ IR00001524/00001

29. Bolanča S. Tehnologija tiska od Gutenberga do danas. Senj Zb Pril Za Geogr Etnologiju Gospod Povij Kult. 2008;35(1):125-45.

30. Povijest Belišća [Internet]. Turistička zajednica Belišće. [cited 2019 Oct 10]. Available from: https:// www.tzbelisce.net/povijest-belisca/

31. Über unser Unternehmen | Diefenbach Verpackungen $\mathrm{GmbH}$ [Internet]. DIEFENBACH VERPACKUNG. [cited 2019 Oct 15]. Available from: https://www.diefenbach-verpackungen.de/ueber_ uns/

32. Alois Senefelder. In: Wikipedia [Internet]. 2019 [cited 2019 Oct 10]. Available from: https:// en.wikipedia.org/w/index.php?title=Alois Senefelder\&oldid $=903314915$

33. Offset printing. In: Wikipedia [Internet]. 2019 [cited 2019 Oct 10]. Available from: https:// en.wikipedia.org/w/index.php?title $=$ Offset printing\&oldid $=918999936$

34. Franjo M. Grafička enciklopedija. Teh Kn Zagreb. 1970; 
35. Flexodruck. In: Wikipedia [Internet]. 2018 [cited 2019 Oct 10]. Available from: https://de.wikipedia.org/w/ index.php?title=Flexodruck\&oldid $=180270615$

36. Meyer K-H. Technik des Flexodrucks. Rek und Thomas; 2006. ISBN-13: 978-3905330175

37. Kiš P. Povijest 20. st. kroz 2000 izložaka ambalaže. :1. [Internet]. [cited 2019 Oct 10] Available from:http:// www.mgz.hr/UserFiles/file/Rodin_Povijest_20_ stoljeca_Jutarnji_list_2002.pdf

38. Janović Z. Polymerization and Polymers. Hrvatsko društvo kemijskih inženjera i tehnologa; 1997. ISBN 953-96041-5-x

39. Nakamura Y, Katogi S. Technology trends and future history of semiconductor packaging substrate material. Hitachi Chem Rev 6. 2013; [Internet]. [cited 2019 Oct 11]. Available from: http://www. hitachi-chem.co.jp/english/report/055/55_sou06.pdf

40. Morris BA. The science and technology of flexible packaging: multilayer films from resin and process to end use. William Andrew; 2016. ISBN: 9780323242738

41. Claudio L. Our food: packaging \& public health. 2012; June 2012 Environmental Health Perspectives 120(6):A232-7 DOI: 10.1289/ehp.120-a232

42. BWC - Infographics-PackagingHist- kk103012. pdf [Internet]. [cited 2019 Oct 11]. Available from:
https://www.bwc.com/pub/files/BWC\%20-\%20 Infographics-PackagingHist-\%20kk103012.pdf

43. Vujković I, Galić K, Vereš M, Plestenjak A. Ambalaža za pakiranje namirnica. Tectus; 2007.

44. Ščetar M. Utjecaj ambalažnih materijala na prehrambene proizvode. [Internet]. [cited 2019 Oct 11]. Available from Sveučilište U Zagrebu. 2010; http://www.podravka.hr/repository/ files/6/9/698c54112628faf7c8ea694ff19d8f60.pdf

45. Wilkinson EP, Harvard University/Asia Center. Chinese history: A new manual. Harvard University Asia Center Cambridge, MA; 2012. ISBN-13: 9780674067158

46. Soroka W. Fundamentals of packaging technology. Inst of Packaging Professionals; 1999. ISBN-13: 9781930268258

47. Hook P, Heimlich JE. a History of packaging. Retrieved Oct. 2000;12:2013. [Internet]. [cited 2019 Oct 11]. Available from: https://ohioline.osu.edu/ factsheet/cdfs-133

48. Lee DS, Yam KL, Piergiovanni L. Food packaging science and technology. CRC press; 2008. ISBN 9780824727796 - CAT\# DK3076

49. Brčić I. Utjecaj ekologije na dizajn ambalaže. 2015; Undergraduate thesis, University North, Varaždin 
